\title{
Empowerment of Nigerian Muslim Households through Waqf, Zakat, Sadaqat and Public Funding
}

\author{
Yusuff Jelili Amuda
}

\begin{abstract}
This study examines the roles and efficiency of waqf properties, zakat, sadaqat, and public funding in transforming and alleviating poverty among the less privileged Nigerian Muslims in particular and Nigerians at large. Many Nigerians are living on less than two dollars per day based on the NAPEP submission in 2013. The majority of Nigerian Muslims are wallowing in abject poverty due to their insufficient and unsustainable means of income. The present situation of some Nigerian Muslims is worsening due to their financial constraints and poverty rate across the Nigeria as a result of uncontrolled corruption confronting the nation and unemployment. The conditions of Nigerian Muslims require urgent improvement financially, educationally, socially and spiritually. In light of this, how can the integration of waqf properties, zakat, sadaqat, and public funding play viable and commendable roles in poverty reduction among Nigerian Muslims. It will further discuss the collected charitable funds that can be used to empower Nigerian Muslim households. The paper concludes with a number of suggestions to remedy the situation and optimize these sources of funding.
\end{abstract}

Index Terms-Nigerian muslims, poverty, waqf property, zakat, Sadaqat, public funding and household empowerment.

\section{INTRODUCTION}

The purpose and effective cause of waqf endowment, zakat, sadaqat, waqf properties and public funding is to reduce poverty in the community and enrich needy Muslims in order to be financially independent. It can be inferred from the Qur'an that Allah (swt) ordained Muslims to pay zakat annually purposely to assist the poor. This meaning can be applied to the mechanisms of sadaqat, waqf endowment, and public funding. Although zakat is obligatory in light of constituting a pillar of Islam, the amount paid for sadaqat, cash waqf, and public funding may turn out to be more than zakat because there is no limit set upon voluntary donations compared to zakat which is governed by specific rules and conditions. It is believed that the integration of such funds under the auspicious of the waqf institutions across Nigeria will immensely transform many lives positively. The institution of waqf has existed from the time of Prophet Muhammad (PBUH) purposely to alleviate poverty among the Muslims. It remains an able and viable tool and instrument to improve and transform many lives financially, economically, educationally, religiously, and socially provided that the institution is consciously managed by the right persons. If the collection and management of zakat,

Manuscript received June 25, 2013; revised August 26, 2013.

Yusuff Jelili Amuda is with Department of Finance, Kulliyyah of Economics and Management SciencesInternational Islamic University, Malaysia (e-mail: yusuffyja@iium.edu.my, akorede4@yahoo.com). sadaqat, and public funding are performed properly and the waqf establishment is given positive consideration without any hindrance from any quarter, the institution will positively impact on present and future societies and social problems would be significantly reduced. The development and future of waqf in Nigeria is expected to grow since public awareness in this century is greater than previous centuries provided that qualified and competent administrators are appointed. Due to the financial constraints of Nigerian Muslims and the rate of poverty in the nation, there is a need to empower households through the zakat, sadaqat, waqf properties, and public funding. In order to reduce poverty among Nigerian Muslims significantly, households should be empowered. There are many ways to empower needy and less privileged Nigerian Muslims such as through gifts, financial support, debt bondage clearance and payment, and free interest loan in addition to involvement in lucrative business transactions, trading, and investment in order to generate income or profit from cash waqf gifted to the institution.

\section{II.THE THEORETICAL CONCEPT OF ZAKAT, SADAQAT, WAQF AND PUBLIC FUNDING}

Zakat is defined as an obligatory duty on financially secure Muslims to donate or pay a specific percentage of his or her wealth to the poor in society. Similarly, sadaqat is also known as a voluntary donation by capable Muslims to the needy fellow Muslims [1]. The aim and objective of these charities is to relieve the pressures on the poor. The word 'waqf' originally derives from the Arabic root verb 'waqafa' which means to hold, to keep or to detain. Linguistically, waqf simply refers to forbidding the movement, transport or exchange of something [2], [3]. Legally, waqf refers to the detention of a specific thing by the owner or appropriator or instructing that all profits or gains be solely awarded to the charity foundation in order to cater for the poor. When the 'waqif' devotes or transfers his/her property to a waqf institution, he/she transfers the ownership to Allah with the intention of being rewarded by Allah for his/her charity. The waqf can be made in written or oral form or any signal that clearly indicates the free will of the mutawalli (donor) to donate his/her property to the waqf institution [4]-[6]. It has been argued that there is no equivalent expression in English to interpret or convey the exact meaning of the Islamic concept of waqf. In spite of this, Bewley proposes that the word 'waqf' literally means confinement or prohibition [6]. The definition and concept of waqf indicates the donor's intent to gift a portion of his/her property for permanent endowment for the purpose of charity and as a financial aid 
for those in need. Once the property is donated to the waqf, the donated property becomes Allah's property and the conditions stipulated by the waqif, who is the donor, should be strictly followed by the management or waqf administrator.

\section{RELIGIOUS AND CHARITABLE ORGANIZATIONS}

Religious and charitable organizations are examined religiously, socially, and civically. Religiously, all charitable activities are considered devotional actions provided it conforms to Islamic principles. Religiously, waqf endowments can act as zakat collection agencies because the collection of zakat is not well administered in Nigeria. Many eligible zakat payers pay their zakat to those whom they think are eligible or in need. Sometimes they give their donations to Muslim scholars to distribute the collected zakat to needy people across the nation. In this study, waqf has the potential to be recognized as a credible and effective institution to collect zakat, sadaqat, and public funding in the interest of less privileged Nigerian Muslims. Waqf staff can be placed in each mosque or central mosque for the collection of zakat, sadaqat, and public funding and the accumulated charities would be remitted to a special account specifically for zakat. There must be separate arrangements that will differentiate zakat from other charitable funds. The accumulated funds would then be distributed according to Islamic principles and will contribute to the betterment of the society. Part of the collected funds excluding zakat can be used for lucrative transactions or investment in the interests of the needy. In addition, religious programmes can be sponsored and organized by the religious institutions across Nigeria. Some religious educational programmes that will benefit and inculcate the fairness of Allah in society should also be organized. Other religious organizations can be registered under waqf endowments. Socially, the much needed aid can be given to the underprivileged in society and Islamic restaurants, hotels, and resorts can be built for the benefit of citizens and visitors for a small and reasonable fee. Housing and other utilities can be constructed and provided for the benefit of the general public particularly the needy. Developers can be contracted to develop waqf land and after the completion of the agreed project, the developers will collect the dividends for an agreed period and later hand over ownership to the waqf endowment to have absolute control and ownership of the developed land for the benefit of the needy. Institutions like waqf can also be responsible for educating the illiterate by organizing many useful programmes for the illiterate youths and the elderly for the purpose of creating an awareness of global development in terms of technology. Educational programmes can be introduced for children, youths, and elders via media agencies across the nation. Many working children can be removed from child-labor and registered in schools. Waqf institutions can be responsible for ensuring they receive proper education. This can be seen as an act of devotion. In light of these potential benefits, the collection of zakat, waqf, sadaqat, and public funding should be administered in strong and formal institutions or ministries that will be in charge of religious affair at the state and federal level to manage the collection and distribution accordingly. It is believed that the endowment and charity will enrich and significantly enhance the financial status of the needy if it is managed properly.

\section{IMPORTANCE OF ZAKAT, SADAQAT, WAQF ENDOWMENT, AND PUBLIC FUNDING}

There is no element of doubt that zakat, sadaqat, public funding, and waqf foundations have many important roles and benefits to the beneficiary directly and donor or payer indirectly. These institutions provide financial support and relief to the beneficiary or recipient while the donor or payer would be rewarded in hereafter. Integrating the above said charities together in a single viable institution in order to manage the collection and distribution will contribute to the betterment of society and the number of beggars in the nation will be significantly reduced. Spiritually and religiously, waqf properties play an important role in widespread religious activities by spending on mosques, paying the salaries of imams, teachers, preachers, and provisions of carpet, water, paying electricity bills and other mosque materials. In Nigeria, there is no organization or society that pays the salaries of imams or Qur'anic and Islamic studies teachers and as such they are forced to search for alternative means of financial assistance. In addition, many Arabic schools in Nigeria need financial support from organizations such as waqf endowment to maintain the Arabic school and to improve the standard of many Arabic schools. Waqf can restructure and re-direct the direction of many Arabic schools across the nation through the introduction of western education that will pave the way for Madrasah graduates to be admitted into Nigerian universities and absorbed under the government as civil servants or employed in the private sector.

Socially, the said charitable tools or instruments can play an important role in many social activities such as marriage assistance for those who are incapable of marrying and unable to provide for his wife, or unable of rendering financial aid for those who are physically and mentally capable of marrying additional wives but his income is insufficient to maintain additional wives. The foundation can assist such persons in order to reduce the percentage of unmarried women in society. On the other hand, charitable institutions can also free debtors from the bondage of debt for being incapable of paying his or her debt in order to protect the debtor's dignity and personality in society and to empower the debtor that will protect him from subsequent debt. For those who are facing accommodation problems or are unable to pay their house rent, the waqf commission can make a provision from integrated funds for such people in order to relieve their burden as a form of ibadah. In addition, the institution can make provisions for health services especially for the poor, needy, and orphans. The commission can also construct its own standard and modern hospital to assist incapable patients while the meager amount of money would be charged to those capable of paying. Those who are suffering from mental problems can be sent to the specialist or psychiatric hospital for proper treatment and the institution would be fully responsible for the payment and medication recommended by the physician. Rendering financial 
assistance to the recipients serves as brotherhood and kindness recommended in the Holy Qur'an as a rewardable act in Islam. The proposed institution is also capable of giving humanitarian services to the victims of natural disaster such as floods, fires, tsunamis, building collapse, and accidents. Morally, the waqf foundation can sponsor many media programs on television and radio programme that will inculcate religious moral and teachings to the citizens across the nation and it should not be limited solely to the Ramadan period. In this regard, the waqf can choose qualified and competent scholars that will pass the message across [7], [8].

\section{FACTORS THAT INFLUENCE THE EMPOWERMENT OF Nigerian MusLims HousEHOLdS TROUGH WAQF, ZAKAT, SADAQAT AND PUBLIC FUNDING}

The following are the factors that influence the integration of the said charities together in order to empower all households rather than certain households. The following discussion invites to the empowerment of households to liberate Nigerian Muslims from financial constraints and bondage.

\section{A. Economic Problems}

The prime factor that influences the empowerment of households that necessitates the integration of zakat, sadaqat, waqf properties, and public funding is the economy because many Nigerian Muslims are facing economic problems due to the high poverty rate. The integration of zakat, sadaqat, waqf properties, and public funding aims to reduce poverty. The following are the reasons and causes for the proposed integration of zakat, sadaqat, waqf properties and public funding [9].

\section{B. Poverty}

Poverty is rife and common in every part of the world and even in the developed world the lives of many adults and children are fraught with deprivation [10]. Poverty can be studied from two approaches; absolute poverty and relative poverty. Absolute poverty refers to a certain minimal living standard which is specified in terms of nutritional level, clothing, and the income required to support an individual [11]. Relative poverty is interpreted in relation to the prevailing living standard of society, recognizing explicitly the interdependence between the poverty line and the entire income distribution [12], [13]. Based on the poverty theory, Nigerian Muslims are facing both absolute and relative poverty due to the rate of poverty and many of them cannot afford to feed themselves and their families adequately because of their low incomes and the size of the family.

In Nigeria, many Muslim adults and children find themselves in a catastrophic situation due to low incomes. The rate of poverty among Nigerian Muslims is alarming where many adults and children are unable to eat properly. Due to that, children flock to the labor market to survive and to help their family. The Nigerian government is the root cause of poverty in Nigeria due to the uncontrolled corruption among its leaders. It is an undeniable fact that past and present governments are failing in their duties. The financial situation of Nigerian Muslims needs to improve by means of a collective responsibility of the community specially the philanthropists among them.

Many Nigerian Muslim philanthropists can change the lives of many of under privileged by empowering them rather than giving them insufficient money daily. If rich people stop their extravagant expenses and many ceremonies and functions and focus on social contribution through the payment of zakat, giving sadaqat, public funding and waqf endowment in their state, and if all the accumulated charities are channeled through to the proper authorities, the money can be properly invested and many lives will change positively and poverty will gradually reduce. It has been stated repeatedly in the Holy Qur'an that wealth is from Allah and must be spent to relieve those who are in need because it is a good deed and has advantages for both the recipients and givers [14].

"That man can have nothing but what he strives for. That (the fruit of) his striving will soon come in sight".

\section{The High Number of Needy}

The number of needy Muslims differs from one state to another due to the percentage of Muslims in a particular state. The large number of needy Muslims is another challenge confronting waqf endowments or charitable institutions due to the small properties to cater for their needs. Due to the large number of needy Muslims there is a need for the integration of the said charities to cater to the huge number of needy Muslims in the nation. It is the duty of waqf institutions to prioritize its programs and methods of allocating funds for needy applicants [15].

In a country of one hundred and seventy million people with Muslims as the majority, in order to cater for the large number of applicants, the institutions in charge of distributing charities have to engage in lucrative businesses that will boost the income through SME. Household empowerment in small and medium enterprises on any lawful and lucrative transaction and investment will also contribute immensely towards poverty reduction [16].

\section{Miserliness or Selfishness}

Some rich people across the nation are well aware of the importance of integrating charities socially, religiously, mentally, physically, and morally. Despite their considerable wealth they refuse to assist others due to their miserliness and fear that their money will finish and find it difficult and cumbersome to give charity to the needy. Islamically, paying obligatory due zakat is compulsory while contribution to waqf or giving sadaqat and public funding is a voluntary act and there is no specific amount to be given out as sadaqat unlike zakat. Nevertheless, the social problem is the responsibility of those capable to render assistance to those who are seriously in need. Therefore, Islamic scholars need to educate the society on the importance of the said charities to the community and society especially for the less privileged. If the collective efforts were made properly and accordingly, the rate of poverty will reduce among the Muslims regardless of their gender, tribe, and sect. There must be a very strong institution at the local, state, and federal level that will monitor and manage the collection of zakat, sadaqat, cash waqf and public funding for the main purpose of poverty alleviation [17]. 


\section{E. Household Empowerment among Nigerian Muslims}

It is believed that integrating zakat, sadaqat collection, public funding and waqf properties under the auspices and control of the Waqf institution across the nation will immensely change and turn many lives positively and also contribute to society socially, educationally, religiously, and morally. It has to bear in mind that the prime reason why the zakat, sadaqat, cash waqf, and public funding are suggested to be integrated is to reduce the poverty in society and remove the hardships of the poor Muslims in Nigeria. This is based on the principle that matters are judged according to their intention. In addition, Muslims are permitted and allowed to transact in any transactions and business provided that such transactions are not contrary to Islamic principles. Based on that, integrated charities can be invested on any lucrative and profitable venture and small and medium enterprise in so long as the aims and objective of integration will be materialized. The necessity of integration cannot necessitate or legalize any prohibited and unlawful goods or commodities to be legal and lawful for transaction and business. So, the principle of harm should be removed and cannot be claimed as a basis for engaging in usury or prohibited transactions. There are many profitable and lawful businesses that entrepreneurs can engage in. If the charities are well managed and monitored by credible persons and without any hindrances from any quarter, the institution will positively impact on the society. Empowerment of the Nigerian Muslim household should focus on any profitable and lucrative transaction that will liberate the needy. Household empowerment cannot be achieved unless there is sufficient income for the institution to help the needy in each state. Therefore, Waqf endowment in each state across the nation can extend their roles and duties into zakat and sadaqat, cash waqf, and public funding where waqf will manage the distribution in accordance with Islamic principles [18]. The collected funds must be diverted to what they are meant for. The focus of household empowerment should be on the following:

\section{F. Education}

Historically, educating people is one of the aims of waqf where waqf properties were used to educate many people in order to develop them mentally, physically, spiritually, and economically. Many teachers were employed to teach students and waqf properties were used to pay their salaries. In the Nigerian context, many children drop out of school due to financial problems. Many students need financial support for which integrated charities can be diverted to cater for many drop outs students while some educative programmes can be introduced to educate women and the elderly especially in religious studies and training on small and medium enterprises. Similarly, the waqf institution should focus on Arabic schools within their state and upgrade the curriculum and syllabus of the Arabic schools to incorporate many western subjects that will benefit Arabic students upon their graduation. This will enable them to communicate in English and qualify them to be employed as government servants. In addition, many students can be sponsored to further their education locally or internationally as a form of human development and empowerment. The collected charities can be used to build waqf schools, colleges, and universities while all efforts should be made have all courses accredited by the Ministry of Education [19], [20].

\section{G. Employment}

There are many methods to create employment for needy Nigerian Muslims. The creation of centers across the state and local government will create jobs for qualified teachers or instructors and business centers will also employ many people that will reduce the percentage of unemployed Muslims. Having waqf industries, small scale businesses, small and medium enterprises, learning centers, vehicles for commercialization, bakeries, farms, poultry, and other transactions that require the employment of workers will create jobs for needy Muslims. Prerogative power should be vested into the institution in charge of collection to produce a master plan as to how to create employment with integrated charities in the best interest of the needy Muslims [21].

\section{H. Accommodation}

The problem of accommodation is a major problem confronting many Nigerian Muslims. If waqf can make adequate provisions to find commendable solutions to the issue of accommodation then many beneficiaries would be happy and appreciate waqf endowment. If the integrated charities do not properly invest in housing projects then the institution can invite developers to develop the project as a joint business where the developer will finance the working capital and labor. The developer will collect the rent for an agreed period and it will later be taken over by the waqf institution. The profit sharing can be 20 percent for the institution and 80 percent for the developer until the developer recovers his cost plus profit [22], [23].

\section{SMALl MEDIUM ENTERPRISES}

Many less privileged Nigerian Muslims lives can be transformed through the small and medium enterprises because SMEs provide a platform for conducting business. Empowering needy Muslims in profitable and lucrative businesses will vehemently and significantly reduce poverty among Nigerian Muslims. The endowment institution can utilize the integration of zakat, sadaqat, cash waqf, and public funding to support needy Nigerian Muslims through small and medium enterprises. This is based on the effective cause and reason behind giving all those charities which is to support poor people in society. The application is left to the authorities or people in charge to consciously plan on how to aid and support the needy. Similarly, charitable management can also plan how to generate income in order to have sufficient and enough income to assist more applicants. Islamic financing modes in small and medium enterprises must be Shariah compliant with an attractive profit margin. There is no legal or moral justification to finance or engage in any prohibited transaction in the small and medium enterprises regardless of the needy [24]. The following are examples of SMEs that the waqf institution can engage in:

\section{A. Mudarabah System in Small and Medium Enterprise}

Mudarabah is an instrument to alleviate poverty among Muslims where the waqf institution provides capital for 
trained and skillful needy applicants to run the business on the agreement that profit would be shared accordingly but the loss will be solely responsible by the institution. The progress of the SME would be monitored and followed up by the waqf institution. When the applicants or needy Muslims have been empowered, then, the money can be collected and given to another group of needy Muslims. The waqf institution acts as the capital provider and provides 100 percent financing to needy Muslims to run the lawful SME and the recipient is the entrepreneur who will manage the agreed project. It is the duty and responsibilities of the entrepreneur to manage the money properly in the interest of others who are in need. The entrepreneur must maintain transparency, truthfulness, piousness, and fear of Allah in managing the capital in his or her interest and society at large [25].

\section{B. Musharakah System in Small and Medium Enterprise}

This type of contract refers to a form of partnership or joint venture in relation to specific lawful and legal business or transactions where the distribution or sharing of profits and loss will be apportioned in an agreement. This type of contract will boost and enhance the contracting parties' income. Similarly, the institution will generate more income to support the needy Muslims. The prime reason in investing in such contracts is to generate more income in order to have sufficient income to cater for the large number of applicants. In order to have sufficient income, the institution in charge of charities collection can partner in any lucrative investment on the basis of a Musharakah contract. The institution has to appoint competent and skillful staff to represent the institution for the agreed investment. Engaging in such a contract will also create employment for the skillful and trained unemployed Muslims in Nigeria [26].

\section{Murabaha System in Small and Medium Enterprise}

Charitable institutions in Nigeria will act as financial institutions where the capital will be given to the needy Muslims who approached the institution indicating his or her intention to transact the business. Due to the lack of capital and their financial constraints, the needy are unable to engage in business. The applicant might like to open a hair saloon, mechanic workshop, furniture workshop, modern car wash, and other lawful and profitable SME. Charitable institutions will purchase the requested merchandise based on the Murabah agreement and the payment may be in the form of installments or a lump-sum payment. It is believed that such financial assistance will empower the recipients and his or her family. When households are empowered then the poverty will alleviate gradually. Due to poverty the charitable institution in charge will finance the SME with intention to reduce poverty and support the applicant financially. The requested working capital would be provided for the less privileged Muslims based on the agreement that such agreement will benefit the applicant and the charitable institution. Recipients may be required to return the given money back at the end of the agreement in order to be used for other needy applicants. The households should be empowered; therefore, the husband and wife should be given enough money to run their business while their children are considered for scholarships [22], [26].

\section{Islamic Financing Modes on (Muzaraha) Farming and Agricultural Equipment and Machinery}

The main reason for the Ijarah mode of contract for small and medium enterprise is to support the entrepreneur in his or her project or business. Institutions like waqf endowment can use the collected charities to purchase modern farm equipment and machineries that would be useful for agriculture or farming in order to empower the less privileged in society. If the farmers are in need of equipment and machineries such as modern tools or tractors that will make their cultivation easier and more convenient for them to cultivate widely and easily. The institution can make such machineries and equipment available and accessible for rent where a certain amount will be charged. Of course, if the farmer cannot avoid the payment, a certain percent of the harvested product can be given to the institution as rent. The given farm product can be used to empower other needy Muslims to sell in the marketplace. Waqf institutions can build shops or malls where some sellers can be employed by the institution to sell farm products at a reasonable price. This also generates employment [27].

\section{E. Commercialization system in Small and Medium Enterprise}

Poverty or financial constraints is considered a hardship to the less privileged due to their inability to provide adequate provisions for their immediate family. Islamic institutions responsible for zakat, sadaqat, cash waqf, and public funds collection can integrate all the collected charities together in order to finance the needs of the needy. In such a situation, if the applicant needs asset or property for commercialization such as commercial vehicles, motorbike, fixed machinery for small and medium enterprises like photocopy machines, washing machines for laundry, restaurant tools and cutlery, canopy, chairs, and table for rent and others. The institution will purchase the stated and needed assets and on the BBA agreement where the needy will pay back the total cost and margin in deferred payment in a very flexible manner. Creation and provision of the listed and stated tools, assets, and property will empower the needy Muslims to stand on their own. Based on that, some adult Muslims will have the opportunity to be employed in such small and medium enterprise. The duty and responsibility of charitable institutions is to encourage the benefactors to employ fellow needy Muslims in their SME in order to reduce poverty in society. Similarly, the institution can have manufacturing shops as small and medium enterprises where competent and skillful employees will be employed to work based on satisfactory wages or salaries. If needy Muslims request from the waqf institution to finance his or her small and medium enterprise where furniture will be made for selling, after all the necessary feasibility tests and procedures have been studied and consciously evaluated, the institution can finance such small and medium projects on the agreement that the benefactor will pay the money back over the agreed period [25], [28].

\section{CONCLUSION}

It can be concluded that the integration of zakat, sadaqat, 
cash waqf and public funding to empower Nigerian Muslim households will contribute tremendously to society if the collected charities are managed properly by the pious. It is the duty of Muslims to be his brother's keeper in deed and in need. Many verses from the Qur'an and Hadith encourage helping and assisting others who are in need financially, morally, and religiously. The institution in charge of charities collection must not abuse the trust entrusted to them. This study strongly believes that integrating the charities will help many less privileged Muslims if the charities are managed properly. The institution in charge of zakat, sadaqat, cash waqf and public funding has to assist needy applicants in securing working capital to run their project successfully. Since the prime cause or reason for merging all these charities together is to remove hardship from less privilege Nigerian Muslims, the waqf institution will source working capital for the applicants for the agreed period. The benefactors have to maintain the given charity judiciously and for the purpose of the allocated charity. The institution will stand and act by financing and providing physical assets or cash to the needy applicants. The recipients have to uphold and respect the agreement between the two parties in the interest of other poor Muslims in Nigeria.

\section{REFERENCES}

[1] S. A. Salih, The Challenges of poverty Alleviation in IDB Member Countries, Saudi Arabia: Islamic Development Bank, 1999, pp. 63-65.

[2] M. Hidayatullah and A. M. Hidayatullah, Principles of Mahomedan Law, 9th ed. Bombay: N. M. Tripathi Private LTD, 1996, pp. 143.

[3] A. Trakic, "The legal and administrative analysis of Waqf in Bosnia and Herzegovina," presented at the International Conference on Waqf Laws and Management: Reality and Prospects, International Islamic University Malaysia, Kuala Lumpur, October 20-22, 2009.

[4] A. Raissouni, Waqf Endowment Scope and Implication, Rabat Morocco: ISESCO, 2001, pp. 13.

[5] M. M. Ahmad and M. Safiullah, "Management of waqf in Bangladesh: towards a sustainable policy formulation," presented at the International Conference on Waqf Laws and Management: Reality and Prospects, International Islamic University Malaysia, Kuala Lumpur, October 20-22, 2009.

[6] H. Ahmed, Strategies to develop Waqf Administration in India, Research Paper No. 50, Islamic and Training Institute, Islamic Development Bank, Jeddah, Saudi Arabia.

[7] M. Halima, "Philanthropy and social justice in South Africa: A dressing underlying causes or mitigating impact?" M.A. Thesis, University of the Witwatersrand, Johannesburg, 2008.

[8] K. Monzer, "Financing the development of awqaf property," presented at the Seminar on Development of Awqaf Organized by IRTI Kuala Lumpur, Malaysia, March 2-4, 1998.

[9] M. Saidouni, "The role of Waqf in safeguarding architectural legacy and realizing sustainable development," Awqaf Journal, no. 19, pp. 69-70, 2010

[10] F. Michael, The Moral Status of Children: Essays on the Rights of the Child, USA: Kluwer Law International, 1997, pp. 85-86.

[11] S. M. Hashim, Income Inequality and Poverty in Malaysia, New York: Rowman \& Littlefield publishers, INC, 1998, pp. 37-38.
[12] S. Ahmad, Inequality and Poverty in Malaysia: Measurement and Decomposition, London: Oxford University Press, 1983, pp. 113.

[13] J. Gree et al., "A Methodology for measuring food poverty applied to Kenya," Journal of Development Economics, vol. 24, no. 1, pp. 59-74, 1986.

[14] A. A. Dirisu, The Islamic Concept of Social Justice, Pakistan: Islamic Ltd, 1984, pp. 122-123.

[15] A. A. A. Al-Maruf Bil-Khasaf, Ahkam al-Awqaf, Bairut: Dar alkotoub ali-Ilimiyah, 1999, pp. 172-195.

[16] Editorial, "Waqf and the financial crisis what waqf can do to the financial crisis," Awqaf Journal, no. 17, pp. 7-9, 2009.

[17] S. A. Salih, The Challenges of poverty Alleviation in IDB Member Countries, Islamic Development Bank, October 1999, pp. 69-77.

[18] A. A. Mohammad, "Waqf role in family," Journal of Awqaf, no. 8, pp. 125-141, 2005.

[19] B. A. A. Badran, Al-Ahkam Al-Wasayah Wal-Awqahf, Egypt: Muassasat Shabab al-Jamiat, 1982, pp. 254-330.

[20] M. Saidouni, "The role of Waqf in safeguarding architectural legacy and realizing sustainable development," Awqaf Journal, no. 19, pp. 66, 2010.

[21] A. N. Abdullah, "Future vision of waqf role in benefiting from young people," Journal of Awqaf, no. 15, pp. 104-140, 2008

[22] A. Jalil and A. M. Ramli, "Waqf instruments for construction contract: an analysis of structure," in Essential Readings in Contemporary Waqf Issues, M. Khaf and S. M. Mahamood, Eds. Kuala Lumpur: Cert publications Sdn. Bhd, 2011, ch. 14, pp. 407-413.

[23] M. Saidouni, "The role of Waqf in safeguarding architectural legacy and realizing sustainable development," Awqaf Journal, no. 19, pp. 59-64, 2010.

[24] A. Lahsasna, "The role of cash waqf in financing micro and medium sized enterprises (MMES): a new Islamic financial approach by using cash waqf model," in Proc. Seventh International Conference-the Tawhidi Epistemology: Zakat and Waqf Economy, Bangi, 2010, pp. 98-118.

[25] A. Kharofa, The Loan Contract in Islamic Law (Shariah): A Comparative with Positive Law, Gombak, Malaysia: International Islamic University Press, 2002, pp. 49-50.

[26] R. H. Nawawi, Islamic Law on Commercial Transactions, Malaysia: CT Publication, 1999, pp. 146-149.

[27] A. M. Juma'a, "Mugharasa on waqf land: status quo and regulation in fiqh and law," Journal of Awqaf, no. 6, pp. 15-34, 2006.

[28] H. Ahmed, "Waqf-based microfinance: realizing the social role of Islamic finance," in Essential Readings in Contemporary Waqf Issues, M. Khaf and S. M. Mahamood, Eds. Kuala Lumpur: Cert publications Sdn. Bhd, 2011, ch. 8, pp. 205-236.

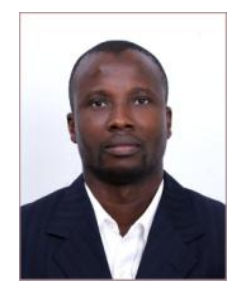

Yusuff Jelili Amuda was born in Ibadan Oyo State, Nigerian. He studied and obtained his B.A. in Shariah from Al-Azhar University, Cairo Egypt and completed his master and doctoral in comparative Laws at Ahmad Ibrahim Kulliyyah of Laws, Malaysia. He later absorbed as a senior lecturer at Sultan Idris Education University, Malaysia between 2010-2012. Yusuff is currently lecturing at Kulliyyah of Economics and Management Sciences, Malaysia as senior lecturer. $\mathrm{He}$ has published numerous articles in reputable local and international journals such as International Journal of Sustainable Development, Scopus, Lambert Academic Publishing, Shariah Law Report, Journal of Islamic Law Review, Malaysian Law Journal, Journal of Al-Risala, Procedia-social and Behavioral Journal, and International Journal of Social Policy. 